\title{
Giant Cell Tumor of the Capitate and Hamate: Case Report and of Literature Review
}

\author{
V. Abdusamad, MBBS ${ }^{1}$ Vivek Singh, MBBS, MS (Ortho) ${ }^{1}$ Rohit Jain, MBBS, MS ${ }^{1}$ \\ Divya Singh, MBBS, MD² \\ ${ }^{1}$ Department of Orthopaedics, All India Institute of Medical Sciences, \\ Rishikesh, Uttarakhand, India \\ 2 Department of Pathology, All India Institute of Medical Sciences, \\ Rishikesh, Uttarakhand, India \\ Address for correspondence Vivek Singh, MBBS, MS (Ortho), \\ Department of Orthopaedics, All India Institute of Medical Sciences, \\ Virbhadra Road, Rishikesh 249203, India \\ (e-mail: singhvr27@gmail.com).
}

J Wrist Surg 2020;9:425-430.

\begin{abstract}
Keywords

- giant cell tumor

- capitate and hamate

- carpal fusion

- tricortical iliac graft

Background In the hand, giant cell tumors (GCTs) of the bones account for 2 to $5 \%$ of all hand tumors; they are often seen in the metacarpals and phalanges, seldom in the carpal bones. In the carpal bones, GCT usually occurs as a single lesion, with multifocal involvement being extremely rare. On analysis of recent English literature, we could find out only two reports having simultaneous involvement of multiple carpal bones. Case Description We report a case of a 29-year-old female with simultaneous involvement of two carpal bones: capitate and hamate. After confirming the diagnosis by histopathological examination, the affected carpals were resected, and the defect was filled with autologous bone graft. Follow-up at 18 months demonstrated no evidence of local recurrence or metastatic disease, and the patient is now having a reasonable hand function.

Literature Review We analyzed nine case reports on GCTs in carpal bones in the past 25 years. Seven out of nine cases that we could analyze showed single carpal bone involvement (three capitate, two scaphoid, one hamate, one triquetrum). In these, four patients had undergone resection, and five patients had undergone curettage, of whom one patient came back 5 months later with recurrence. Only two cases were there with simultaneous involvement of multiple carpal bones. Both the cases were managed with resection and reconstruction with autologous graft iliac graft.

Clinical Relevance GCTs of the carpal bones are relatively rare, and simultaneous involvement of two bones is rarer. Every attempt should be made to preserve useful wrist range of motion by excision and limited carpal fusion.
\end{abstract}

Giant cell tumors (GCTs) of the bone accounts for approximately $5 \%$ of primary bone tumors. ${ }^{1-4}$ They are most frequently located in the metaepiphyses of the long bones, more commonly at the knee and distal radius, followed by the sacrum. In the hand, GCTs of the bone account for 2 to $5 \%$ of all hand tumors; they are most often seen in the metacarpals and phalanges and rarely in the carpal bones. ${ }^{1,2}$

Most cases of GCTs in the carpal bones consist of a single lesion, with multifocal involvement being very rare. ${ }^{5}$

received

March 21, 2020

accepted

April 7, 2020

published online

May 20, 2020
Plain radiographs show radiolucent, expansile lesion with indistinct borders involving the epiphyseal bone, with or without cortical destruction and extension into the soft tissues. ${ }^{1-4}$ Even though GCT is histologically benign, it tends to recur after treatment with intralesionalcurettage ${ }^{1}$ due to its local aggressiveness. Therefore, most hand surgeons prefer to perform en bloc tumor excision with wrist arthrodesis or proximal row carpectomy in cases of cortical erosion or multifocal involvement. ${ }^{4}$

Copyright $\odot 2020$ by Thieme Medical Publishers, Inc., 333 Seventh Avenue, New York, NY 10001, USA.

DOI https://doi.org/ 10.1055/s-0040-1710527. ISSN 2163-3916. 


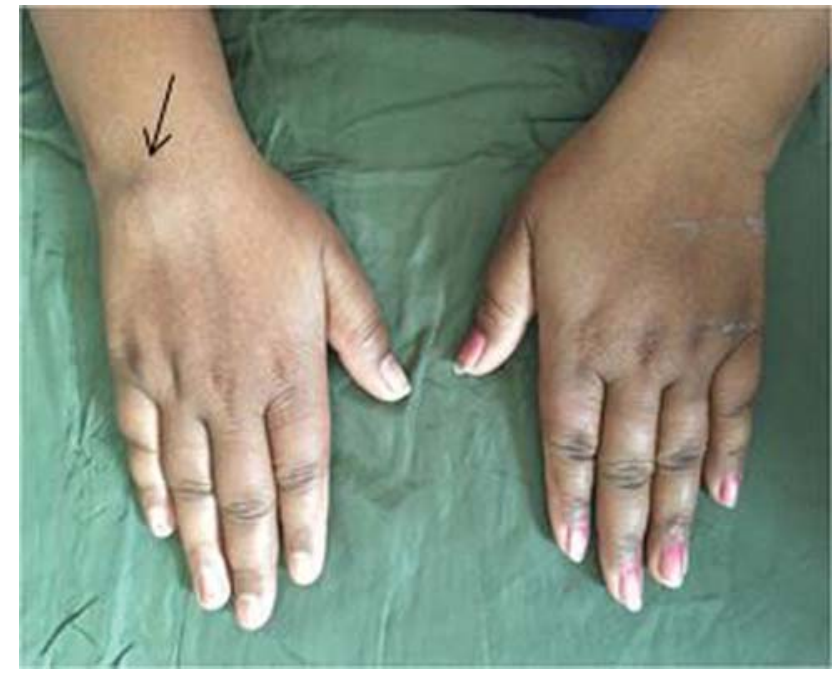

Fig. 1 Photograph showing swelling over the dorsum of the right wrist.

\section{Case Report}

A 29-year-old right-handed woman presented with a 1-year history of pain and localized swelling at the dorsum of the right wrist. She denied any history of wrist and hand trauma. Physical examination showed swelling, tenderness, and decreased range of motion (ROM) of the wrist joint (-Fig. 1). Routine blood laboratory values including thyroid profile were within normal limits.

Standard radiographs of the right wrist showed osteolysis of the capitate and hamate, with areas of cortical destruction (-Fig. 2).
A magnetic resonance imaging (MRI) was performed (-Fig. 3), which confirmed abnormal bone marrow signal throughout the capitate and hamate, with homogenously intermediate signals present on T1-weighted imaging and diffusely hyperintense signals on STIR (short tau inversion recovery) images.

A core biopsy was performed to confirm the diagnosis. Histopathological examination (-Fig. 4) showed many multinucleate giant cells dispersed amidst sheets of mononuclear cells, and the individual cells were round to oval in shape having bland nuclear chromatin and pale cytoplasm, suggesting GCT. The possibility of brown tumors due to hyperparathyroidism has been ruled out through blood investigation.

After confirming the diagnosis, the affected carpal bones along with any macroscopic soft tissue were resected through a dorsal approach to the wrist (-Fig. 5) and the defect was filled with a carefully shaped autologous tricortical iliac crest bone graft, and limited wrist arthrodesis was achieved between the lunate and triquetrum proximally and the third, fourth, and fifth metacarpals distally (-Fig.6). Wrist ROM between the radius and proximal carpal row was well preserved. After skin closure, a volar slab in functional hand position was applied for 6 weeks. Grip strengthening exercises and wrist ROM exercises were started thereafter.

Time period: the patient has been followed up for 18 months postsurgery.

\section{Discussion}

GCTs are an uncommon tumor of the wrist bones. Averill et al reported 2 GCTs in the hamate and trapezoid bones among

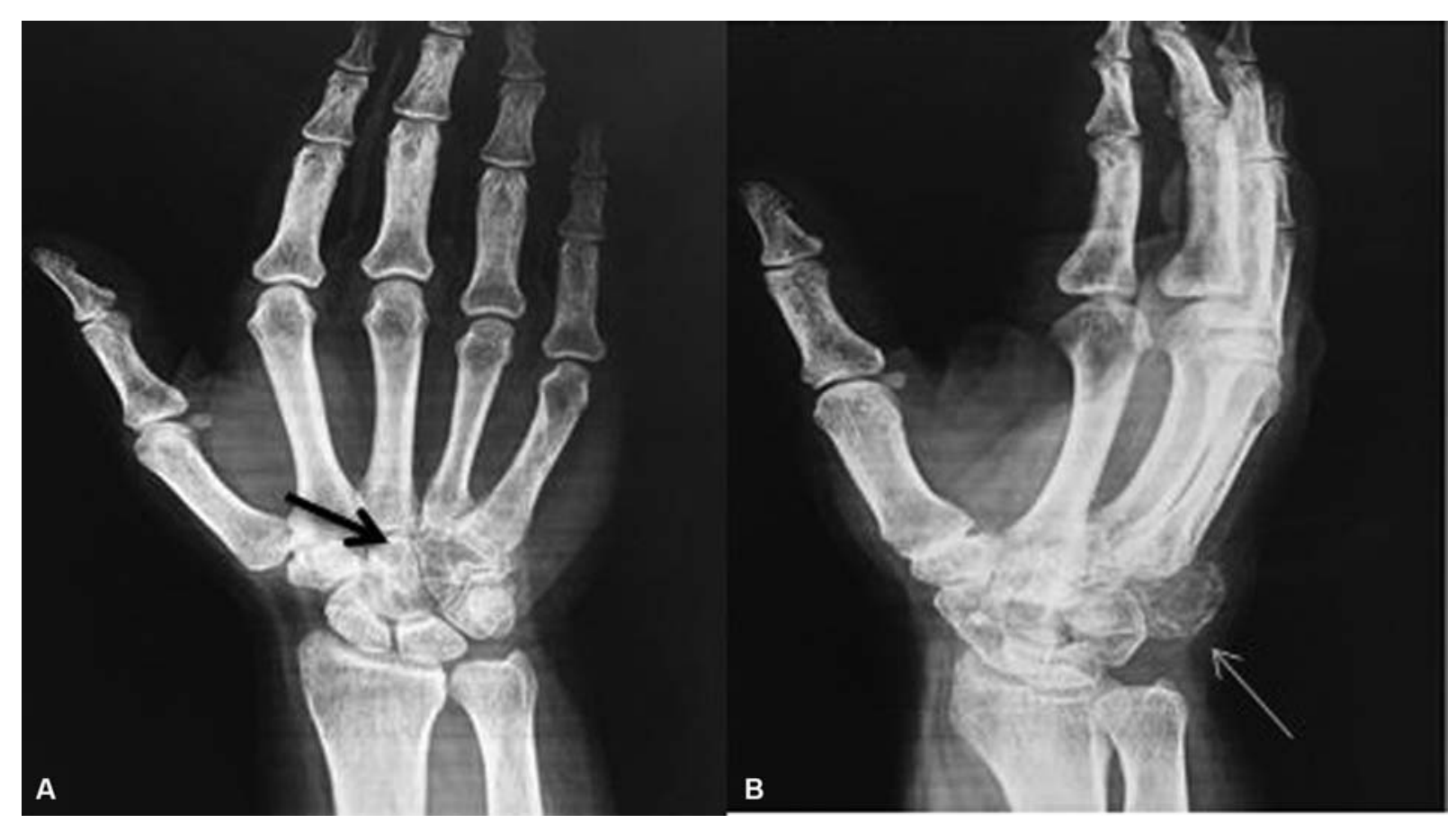

Fig. 2 (A, B) Plain radiograph of the wrist showing osteolysis of the capitate and hamate, with areas of cortical destruction. 

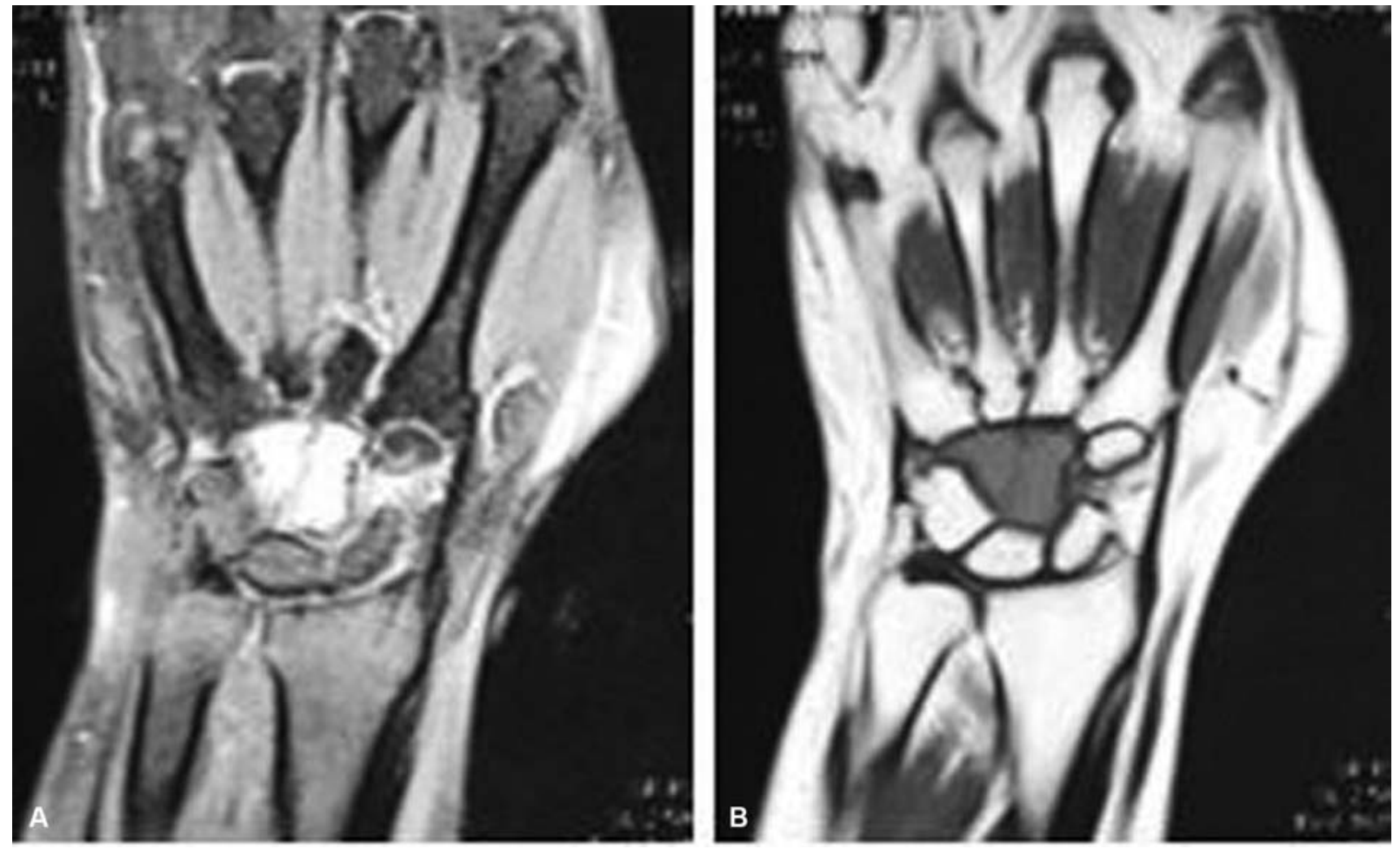

Fig. 3 (A, B) Magnetic resonance imaging coronal sections showing homogenously intermediate signal mass in the capitate and hamate in T1weighted imaging and diffusely hyperintense signal on STIR (short tau inversion recovery) image (1.5 T).

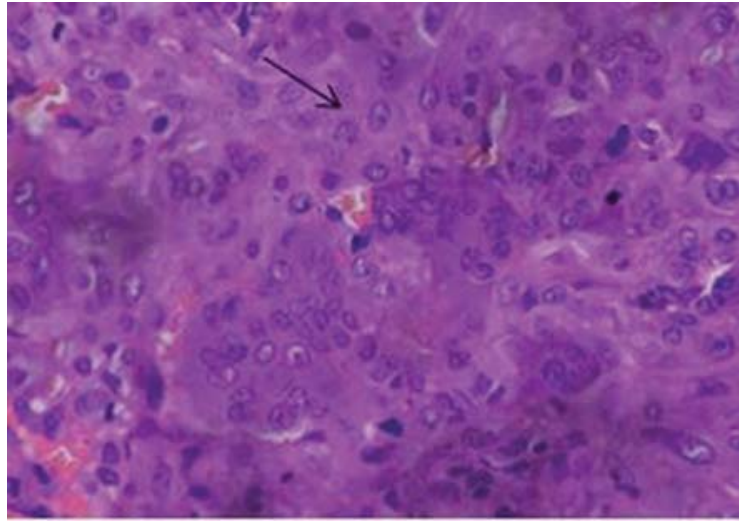

Fig. 4 Histopathology: multinucleate giant cell dispersed amidst sheets of mononuclear cells (hematoxylin-eosin staining, $400 \times$ ).

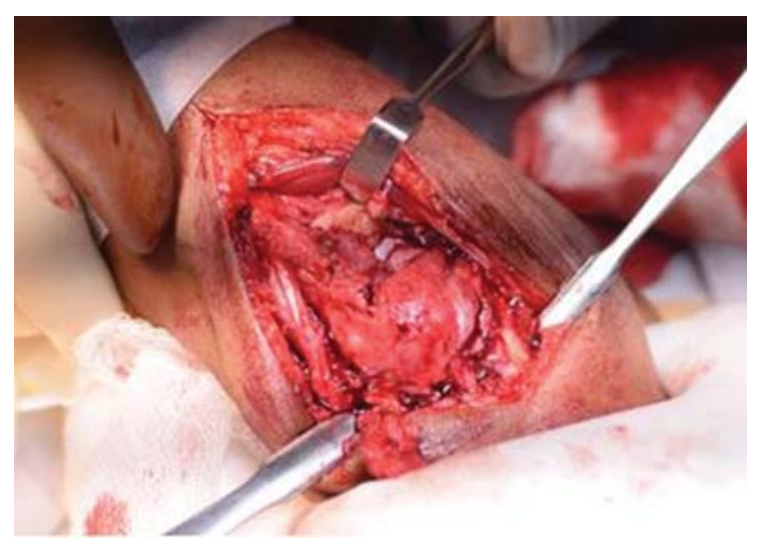

Fig. 5 Tumor involving the capitate and hamate on dorsal approach to the wrist.

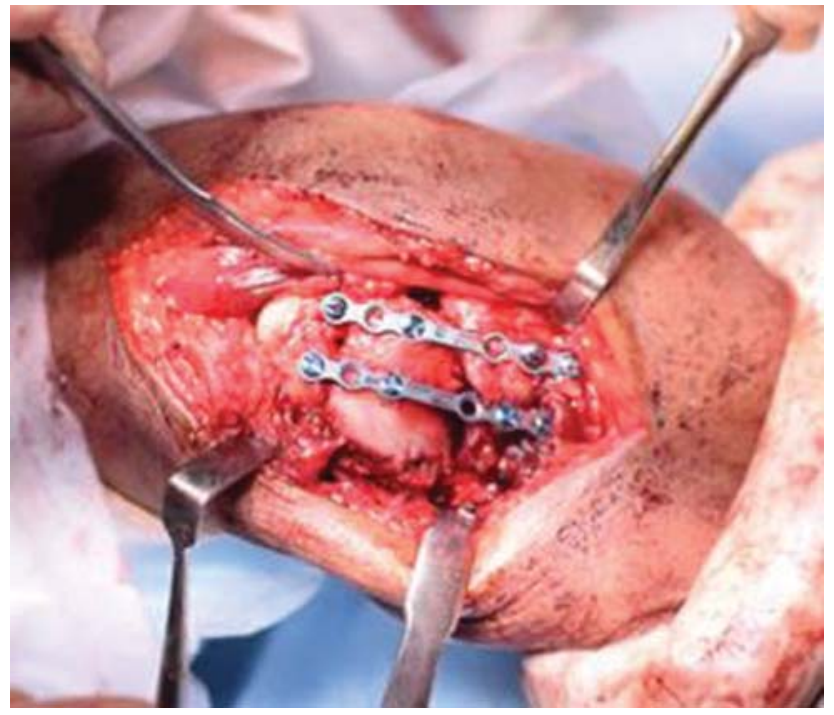

Fig. 6 Arthrodesis between the lunate and triquetrum proximally and the third, fourth, and fifth metacarpals distally using a miniplate.

28 GCTs of the hand and wrist bones. ${ }^{2}$ In a review of 1,228 GCTs from 20 articles, there were 4 GCTs in the hamate, lunate, and scaphoid bones. ${ }^{2}$ In a review of 28,600 primary neoplasms of the carpal bones between 1909 and 1990, there were two GCTs of the capitate among the five GCTs of the wrist bones. ${ }^{6}$

Two general treatment strategies have been used for the treatment of bone GCTs in the hand: (1) Intralesional procedures including curettage with or without bone grafting and (2) excisional procedures including excision of the 
affected carpus, wide excision, and amputation. Although GCTs are almost always benign, these tumors are locally aggressive and tend to have a high recurrence rate (probably $60 \%$ or greater) after treatment by curettage and bone grafting. $^{7-9}$

We analyzed nine case reports on GCT in carpal bones in the past 25 years (-Table $\mathbf{1}$ ). Seven out of nine cases that we could analyze showed single carpal bone involvement (three capitate, two scaphoid, one hamate, one triquetrum). Of these patients, four had undergone resection and five had undergone curettage, of who one came back 5 months later with recurrence in the hamate and the base of the second, third, and fourth metacarpals, which was managed with resection of the capitate, part of the hamate,

Table 1 Summary of review of the literature on GCTs of the carpal bones

\begin{tabular}{|c|c|c|c|c|c|c|c|c|}
\hline No. & Authors & Year & Age & Sex & Bone(s) & Duration & Treatment & Outcome \\
\hline 1 & Abdu et al $^{10}$ & 1994 & 30 & $M$ & Scaphoid & $6 \mathrm{mo}$ & $\begin{array}{l}\text { Resection and silicone } \\
\text { implant }\end{array}$ & $\begin{array}{l}\text { Mild reactive silicone } \\
\text { synovitis Good wrist } \\
\text { function and no evi- } \\
\text { dence of recurrent } \\
\text { disease }\end{array}$ \\
\hline 2 & Gupta et $\mathrm{al}^{5}$ & 1995 & 30 & $M$ & $\begin{array}{l}\text { Capitate, } \\
\text { hamate, and } \\
\text { triquetrum }\end{array}$ & & $\begin{array}{l}\text { Distal row carpectomy } \\
\text { with reconstruction of } \\
\text { the left wrist with a } \\
\text { bicortical iliac autoge- } \\
\text { nous bone graft and ar- } \\
\text { throdesis of the distal } \\
\text { carpal segment to } \\
\text { metacarpals }\end{array}$ & $\begin{array}{l}\text { No recurrence with } \\
\text { good hand function on } \\
\text { 18-mo follow-up }\end{array}$ \\
\hline 3 & Kew et al ${ }^{11}$ & 2000 & 18 & $\mathrm{M}$ & Scaphoid & $2 \mathrm{mo}$ & $\begin{array}{l}\text { Resection and a prona- } \\
\text { tor quadratus pedicle } \\
\text { bone grafting with } \\
\text { radioscaphoid fusion }\end{array}$ & $\begin{array}{l}\text { No recurrence was } \\
\text { found on 7-y follow-up }\end{array}$ \\
\hline 4 & $\begin{array}{l}\text { Sakayama } \\
\text { et al }\end{array}$ & 2008 & 24 & $\mathrm{~F}$ & Hamate & $3 \mathrm{mo}$ & $\begin{array}{l}\text { Curettage with acrylic } \\
\text { cementation }\end{array}$ & $\begin{array}{l}\text { No recurrence with } \\
100 \% \text { functional recov- } \\
\text { ery on 3-y follow-up }\end{array}$ \\
\hline 5 & Tarng et $a^{13}$ & 2009 & 29 & $\mathrm{~F}$ & $\begin{array}{l}\text { Scaphoid, } \\
\text { capitate, } \\
\text { trapezium, } \\
\text { and trapezoid }\end{array}$ & & $\begin{array}{l}\text { En bloc resection } \\
\text { through a dorsal and } \\
\text { volar approach for soft } \\
\text { tissue resection, with } \\
\text { defect filled autologous } \\
\text { with bicortical iliac crest } \\
\text { bone graft }\end{array}$ & $\begin{array}{l}\text { No evidence of clinical } \\
\text { and radiological evi- } \\
\text { dence of recurrence on } \\
1 \text {-y follow-up }\end{array}$ \\
\hline 6 & Kotnis et $\mathrm{al}^{14}$ & 2009 & 44 & $M$ & Triquetrum & $8 \mathrm{mo}$ & $\begin{array}{l}\text { Surgical exploration } \\
\text { and local curettage }\end{array}$ & $\begin{array}{l}\text { The patient was symp- } \\
\text { tom-free till for } 4 \mathrm{~m}\end{array}$ \\
\hline 7 & Angelini et al $^{15}$ & 2011 & 21 & $\mathrm{~F}$ & Capitate & $7 \mathrm{mo}$ & $\begin{array}{l}\text { Curettage + phenol ab- } \\
\text { lation + morselized cor- } \\
\text { ticocancellous bone } \\
\text { allograft }\end{array}$ & $\begin{array}{l}\text { Recurrence noticed af- } \\
\text { ter } 5 \text { mo }\end{array}$ \\
\hline 8 & Oufkir et al ${ }^{16}$ & 2017 & 48 & $\mathrm{~F}$ & Capitate & $1 \mathrm{y}$ & $\begin{array}{l}\text { Staged procedure } \\
\text { Curettage and bone } \\
\text { cement } \\
\text { Corticocancellous } \\
\text { bone graft from the iliac } \\
\text { crest, with lunometa- } \\
\text { carpal arthrodesis }\end{array}$ & $\begin{array}{l}\text { Complex regional pain } \\
\text { syndrome in the early } \\
\text { postoperative period } \\
2 \text { y after surgery: pain- } \\
\text { free with functional } \\
\text { range of motion } \\
\text { ( } 30 \text { degrees of exten- } \\
\text { sion, } 25 \text { degrees of } \\
\text { flexion), the grip } \\
\text { strength was } 50 \% \text { of } \\
\text { that of the unaffected } \\
\text { side }\end{array}$ \\
\hline 9 & Afsharet al ${ }^{17}$ & 2018 & 16 & $\mathrm{~F}$ & Capitate & $6 \mathrm{mo}$ & $\begin{array}{l}\text { Intralesional curet- } \\
\text { tage }+ \text { alcohol abla- } \\
\text { tion }+ \text { allogenic bone } \\
\text { graft }\end{array}$ & $\begin{array}{l}\text { Satisfactory hand func- } \\
\text { tion without any recur- } \\
\text { rence at 2-y follow-up }\end{array}$ \\
\hline
\end{tabular}

Abbreviations: F, female; GCT, giant cell tumor; M, male. 


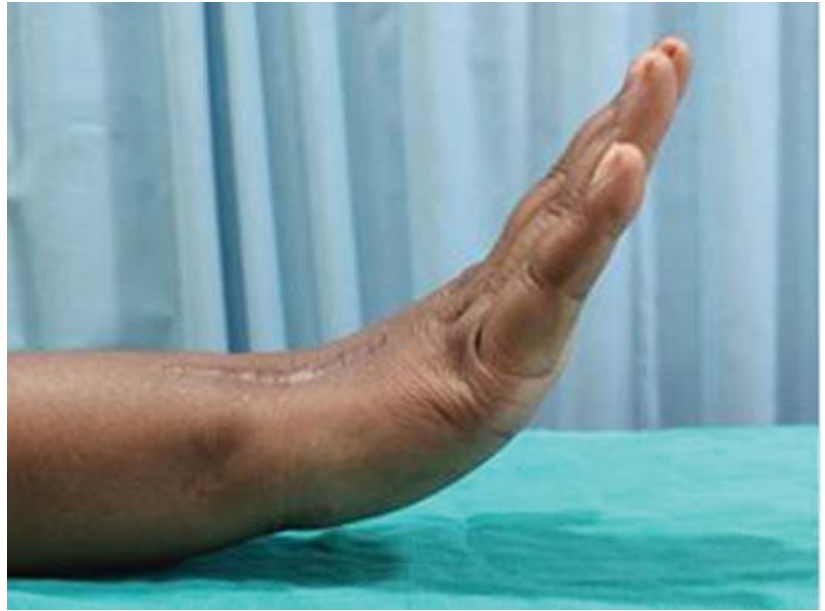

Fig. 7 Range of motion of the wrist after 18 months.

and the base of the third metacarpal, phenol application, and carpometacarpal arthrodesis with autologous iliac crest bone graft.

Only two reports in the English literature shows simultaneous involvement of multiple carpal bones. In the first case, which was reported by Gupta et al, there was simultaneous involvement of the capitate, hamate, and triquetrum, which was managed with distal row carpectomy with reconstruction of the left wrist with a bicortical iliac autogenous bone graft and arthrodesis of the distal carpal segment to metacarpals, and there was no recurrence, with good hand function on 18-month follow-up. The second case was reported by Tarng et al in 2008 in which the scaphoid, capitate, trapezium, and trapezoid were involved and was managed with en bloc resection through a dorsal and volar approach for soft tissue resection, the defect was filled with autologous bicortical iliac crest bone graft, and there was no clinical and radiological evidence of recurrence on 1 year of follow-up.

Ours is the only third case with simultaneous involvement of two carpal bones. In our patient, 18-month follow-up demonstrated no evidence of local recurrence or metastatic disease. The patient is now experiencing a reasonable functional ROM (wrist flexion of 35 degrees, wrist extension of 40 degrees, ulnar deviation of 10 degrees, radial deviation of 5degrees) (-Fig. 7) and a good hand grip. Check X-ray showed good fusion with preservation of radiolunate articulation (-Fig. 8).

\section{Conclusion}

GCTs of carpal bones are relatively rare, and simultaneous involvement of two bones is rarer. Every attempt should be made to preserve useful wrist ROM by excision and limited carpal fusion.

Note

This work was performed at All India Institute of Medical Sciences (AIIMS), Rishikesh, Uttarakhand, India.

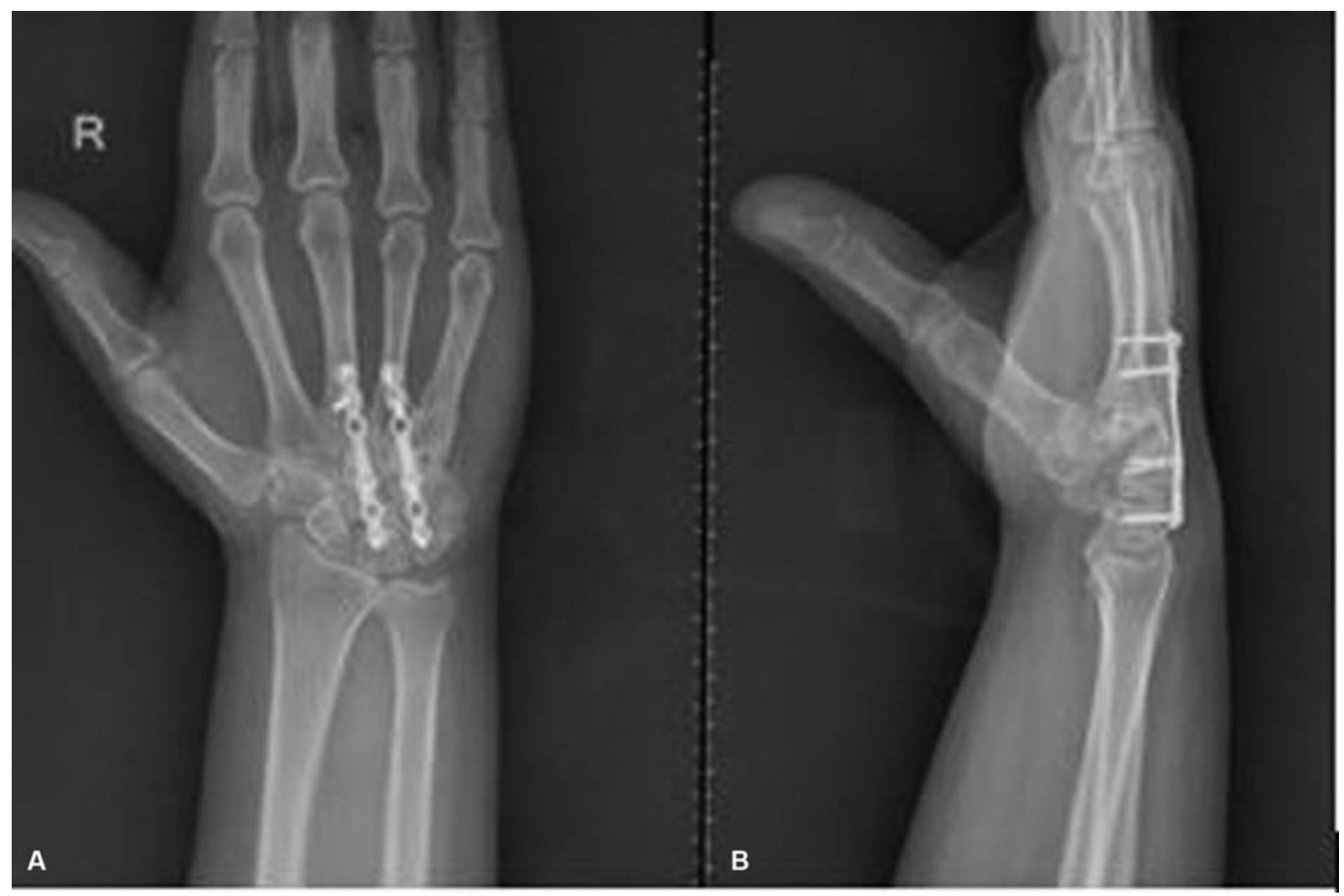

Fig. 8 (A, B) Postoperative X-ray on 18-month follow-up after surgery. 


\section{Conflict of Interest}

None declared.

\section{Acknowledgments}

We thank our seniors and colleagues in our institute who helped us to publish this case by providing articles on GCTs that includes carpal bones.

\section{References}

1 Shigematsu K, Kobata Y, Yajima H, Kawamura K, Maegawa N, Takakura Y. Giant-cell tumors of the carpus. J Hand Surg Am 2006; 31(07):1214-1219

2 Averill RM, Smith RJ, Campbell CJ. Giant-cell tumors of the bones of the hand. J Hand Surg Am 1980;5(01):39-50

3 McDonald DJ, Schajowicz F. Giant cell tumor of the capitate. A case report. Clin Orthop Relat Res 1992;(279):264-268

4 Howard FM, Lassen K. Giant cell tumor of the capitate. J Hand Surg Am 1984;9(02):272-274

5 Gupta GG, Lucas GL, Pirela-Cruz M. Multifocal giant cell tumor of the capitate, hamate, and triquetrum: a case report. J Hand Surg Am 1995;20(06):1003-1006

6 Murray PM, Berger RA, Inwards CY. Primary neoplasms of the carpal bones. J Hand Surg Am 1999;24(05):1008-1013

7 Goldenberg RR, Campbell CJ, Bonfiglio M. Giant-cell tumor of bone. An analysis of two hundred and eighteen cases. J Bone Joint Surg Am 1970;52(04):619-664
8 Johnson EW Jr, Dahlin DC. Treatment of giant-cell tumor of bone. J Bone Joint Surg Am 1959;41-A(05):895-904

9 Hutter RVP, Worcester JN Jr, Francis KC, Foote WF Jr, Stewart FW. Benign and malignant giant cell tumors of bone. A clinicopathological analysis of the natural history of the disease. Cancer 1962; 15:653-690

10 Abdu W A, Murphy LM, Memoii VA. Giant cell tumor of the scaphoid: a case report and review of the literature. J Hand Surg Am 1994;19(06):1003-1005

11 Kew J, Kumta SM, Leung PC. Case reports. Giant cell tumour in the scaphoid bone. ClinRadiol 2000;55(09):717-718

12 Sakayama K, Sugawara Y, Kidani T. Giant cell tumour of the hamate treated successfully by acrylic cementation: a case report. J Hand Surg Eur Vol 2008;33(06):803-805

13 Tarng YW, Yang SW, Hsu CJ. Surgical treatment of multifocal giant cell tumor of carpal bones with preservation of wrist function: case report. J Hand Surg Am 2009;34(02): 262-265

14 Kotnis NA, Davies AM, Kindblom LG, James SLJ. Giant cell tumour of the triquetrum. Skeletal Radiol 2009;38(06): 593-595

15 Angelini A, Mavrogenis AF, Ruggieri P. Giant cell tumor of the capitate. MusculoskeletSurg 2011;95(01):45-48

16 Oufkir AA, Lazerges C, Coulet B, Chammas M. Giant cell tumor of the capitate treated with excision and midcarpal fusion. J Wrist Surg 2017;6(03):238-243

17 Afshar A, Tabrizi A, Aidenlou A, Abbasi A. Giant cell tumor of the capitate bone. J Hand Microsurg 2018;10(03):158-161 